\title{
Bathymetric roughness of the Southeast Indian Ridge: Implications for crustal accretion at intermediate spreading rate mid-ocean ridges
}

\author{
L. Ying Ma and James R. Cochran \\ Lamont-Doherty Earth Observatory of Columbia University, Palisades, New York
}

\begin{abstract}
The nature of the transition from axial highs to axial valleys at mid-ocean ridges and the physical processes involved in the transition are important for understanding how axial morphology changes with spreading rate, mantle temperature, and lithospheric strength at midocean ridges. In order to provide observational constraints on the nature of the changes in axial morphology, we examined the regional- and segment-scale variations in axial and flank morphology at the intermediate spreading Southeast Indian Ridge (SEIR) using newly collected geophysical data. An empirical orthogonal function analysis was used to separate regional and local components of the topography field and to estimate bathymetric roughness. Three distinct types of axial morphology were identified from the regional component of ridge topography in our area: axial highs, shallow axial valleys, and "Mid-Atlantic Ridge-type" deep axial valleys. Axial depth increases by $\sim 2100 \mathrm{~m}$ from $88^{\circ} \mathrm{E}$ and $118^{\circ} \mathrm{E}$, while off-axis depth only increases by $\sim 500 \mathrm{~m}$. In addition, except for one segment with a deep axial valley, there is little change in off-axis depth within segments, in contrast to the large intrasegment variations in axial depth. These observations indicate that the overall and intrasegment variations in crustal thickness are much smaller than would be predicted from the variations in axial depth and that the major portion of the variations in ridge axis depth are dynamically supported. There are step-like increases in bathymetric roughness as axial morphology changes from an axial high to a shallow axial valley and from a shallow axial valley to a deep axial valley. The step changes in roughness imply that the change from one mode of axial morphology to another is accompanied by an abrupt change in the strength of the lithosphere. The abrupt changes in lithospheric strength may be due to the existence of a "threshold" mantle temperature or crustal thickness about which the lithospheric strength is very sensitive to small fluctuations. Systematic intrasegment variations in roughness are also observed. Roughness shows V-shaped patterns within segments with axial highs but no clear pattern within segments with axial valleys. The different patterns in roughness at axial highs and axial valleys on the SEIR may result from the presence or absence of a magma chamber. The presence of a magma chamber at a ridge segment with an axial high implies weaker axial lithosphere and hence lower roughness near the center of segments relative to the segment ends.
\end{abstract}

\section{Introduction}

The distinct differences in morphology between fast spreading ridges, where $-400 \mathrm{~m}$ axial highs are typically found, and slow spreading ridges, where deep ( $>1000 \mathrm{~m}$ ) axial valleys are found, have been well documented [e.g., Heezen, 1960; Menard, 1960; Macdonald, 1986, 1989]. The nature of the transition from an axial high to an axial valley and the physical processes involved in the transition have received considerable attention in recent years, because they are important for understanding how axial tectonics change with variations in spreading rate, mantle temperature, and lithospheric strength and what processes control crustal accretion at mid-ocean ridges [e.g., Sleep, 1969; Tapponnier and Francheteau, 1978; Phipps Morgan et al., 1987; Parmentier and Phipps Morgan, 1990; Chen and Morgan, 1990; Phipps Morgan and Chen, 1993a,b].

Copyright 1997 by the American Geophysical Union.

Paper number 97JB01280

$0148-0227 / 97 / 97 . \mathrm{B}-01280 \$ 09.00$
The different forms of axial morphology represent very different styles of axial tectonics. Since most ridge flank morphology is generated near the ridge axis, it is reasonable that variations in the tectonics responsible for axial morphology may result in variations in ridge flank morphology. Bathymetric roughness, which is generated primarily by abyssal hills, therefore represents an indirect record of the axial morphology and can provide observational constraints on the nature of changes in axial morphology and tectonics and thus of the processes of crustal accretion at midocean ridges. If there is a continuous change in axial morphology from an axial high to an axial valley, as suggested by compilations of axial relief [Macdonald, 1986] and some classes of models for the creation of axial relief [e.g., Phipps Morgan et al., 1987], then a continuous change of ridge flank morphology is expected. On the other hand, if there are distinct modes of axial morphology, then there should be distinct changes in the properties of the ridge flank abyssal hilIs.

Previous studies have related flank roughness to spreading rate variations and ridge segmentation [Small, 1994; Goff et al., 1993, 1995; Malinverno, 1991; Malinverno and Cowie, 
1993; Hayes and Kane, 1991]. It has been shown, for example, that flank roughness increases with decreasing spreading rate for rates less than $75 \mathrm{~mm} / \mathrm{yr}$ but becomes roughly constant at greater rates [Small, 1994; Malinverno, 1991; Malinverno and Cowie, 1993; Hayes and Kane, 1991]. Goff et al. (1993, 1995) found that abyssal hill height tends to be largest toward segment ends and smallest in the center of segments at the fast spreading East Pacific Rise (EPR), but tends to decrease along the entire length of segments from inside to outside corners at the slow spreading Mid-Atlantic Ridge (MAR). However, the lack of the detailed studies at intermediate spreading rate ridges makes it difficult to demonstrate and understand how flank morphology changes as axial morphology changes from one form to another.

The Southeast Indian Ridge (SEIR) is an intermediate spreading ridge with significant systematic variations in axial morphology [Small and Sandwell, 1992, 1994; Ma and Cochran, 1996], which makes it a prime area to examine how axial morphology changes from one state to another at the same spreading rate and to place constraints on the theoretical models of crustal accretion processes influencing axial morphology. Spreading rate is reasonably constant (72-76 $\mathrm{mm} / \mathrm{yr}$ ) along the SEIR, so the major influence on the form of the axial morphology appears to be variations in mantle temperature. Ma and Cochran [1996] found that there are three distinct forms of axial morphology along this intermediate spreading rate ridge: axial highs, shallow axial valleys, and deep axial valleys. Transitions between the various types of axial morphology occur over relatively short distances and are accompanied by large changes in axial relief, bathymetric roughness, and magnetic anomaly amplitude, supporting models with a "threshold" mechanism for a rapid change between different forms of axial morphology [Ma and Cochran, 1996].

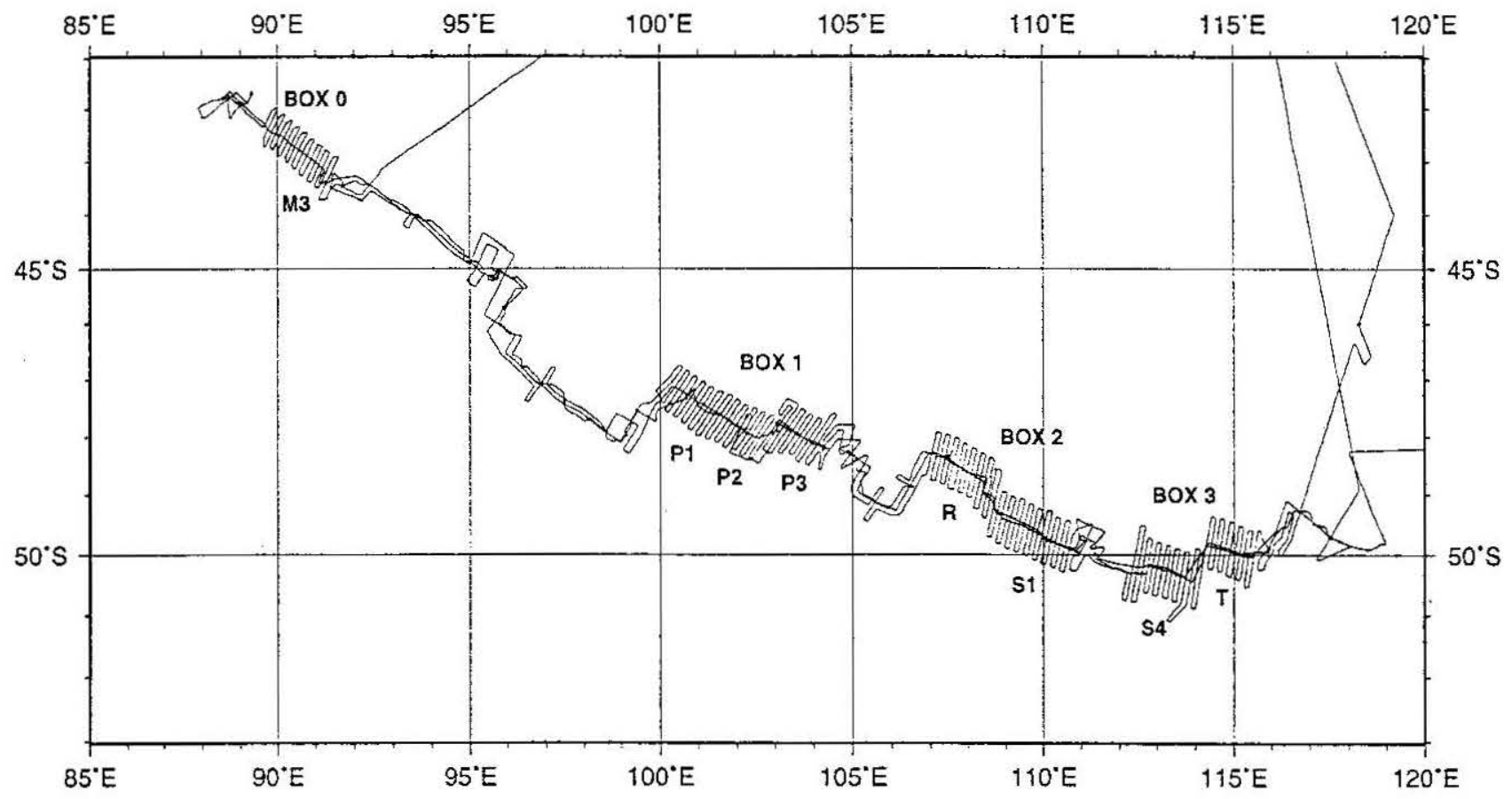

The above results, however, were based on satellite gravity data [Small and Sandwell, 1992, 1994] and widely spaced individual shipboard profiles collected more than 20 years ago [Ma and Cochran, 1996], which provided us with little opportunity to locate exactly where and how the transition from an axial high to an axial valley occurs at the SEIR and allowed us to only study the large-scale variations in axial morphology and flank morphology. A detailed geophysical survey (SeaBeam 2000, gravity and magnetics) of the SEIR was conducted between $88^{\circ} \mathrm{E}$ and $118^{\circ} \mathrm{E}$ from December 1994 to February 1995 (Figure 1) [Sempéré et al., 1997, Cochran et al., 1997]. These new data provide us with the opportunity to explore in detail how axial morphology changes along the SEIR, how these changes influence ridge flank morphology, and to refine our understanding of the processes of crustal accretion and abyssal hill generation at intermediate spreading rate ridges.

In this paper, we present results of an empirical orthogonal function (EOF) analysis [Small, 1994], an approach which decomposes the bathymetry into a series of orthogonal modes allowing bathymetric roughness to be separated from the basic shape of the ridge axis. We examine regional- and segmentscale variations in axial morphology and bathymetric roughness and explore the processes responsible for these variations.

\section{Data and Method}

A $2300 \mathrm{~km}$ long section of the ridge axis between $88^{\circ} \mathrm{E}$ and $118^{\circ} \mathrm{E}$ on the SEIR was surveyed during a two-leg field program on the $\mathrm{R} / \mathrm{V}$ Melville, which includes four survey areas identified as box 0 to box 3 . The four detailed survey boxes extend for $1100 \mathrm{~km}$ along the axis and consist of eight secondorder segments (Figures 1 and 2). Within each area, survey

Figure 1. Track coverage of the Southeast Indian Ridge (SEIR) obtained during the two-leg field program on the R/V Melville. A $2300 \mathrm{~km}$ long section of the ridge axis was surveyed between $88^{\circ} \mathrm{E}$ and $118^{\circ} \mathrm{E}$ including four detailed survey areas identified as box 0 to box 3. Letters under detailed survey boxes identify second-order segments using the naming system of C. Small et al. (The structure and segmentation of the Southeast Indian Ridge, submitted to Marine Geology) and Cochran et al. (1997). 

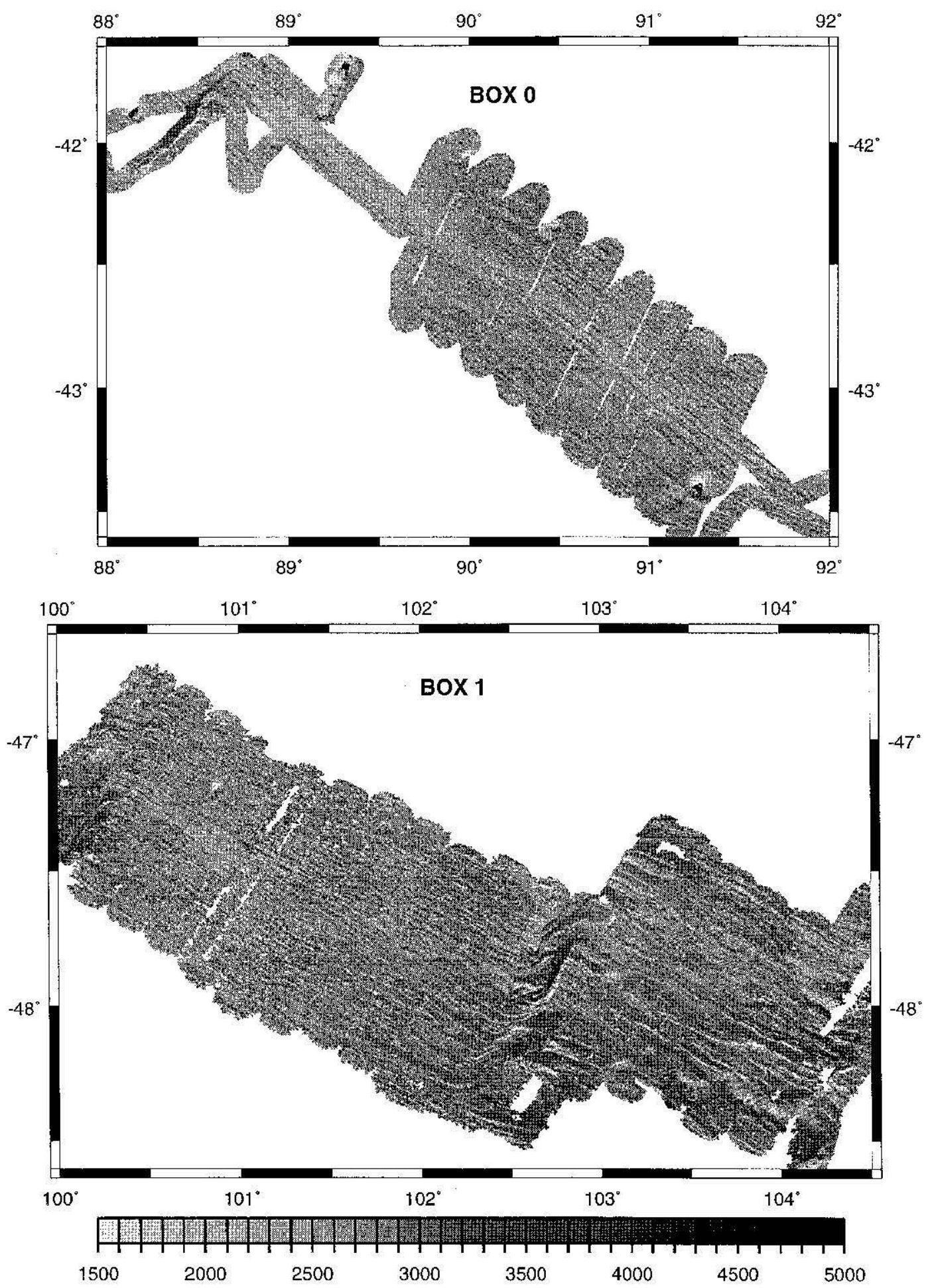

Figure 2a. Shaded relief SeaBeam bathymetric maps for survey areas denoted box 0 and box 1 . Maps are illuminated from the north in order to emphasize the abyssal hill fabric on the ridge flanks.

lines cross nearly perpendicular to the ridge axis at $9 \mathrm{~km}$ intervals and extend out about $45 \mathrm{~km}$ from the axis on each flank.

The present total spreading rate along this portion of the SEIR is nearly constant at $\sim 75 \mathrm{~mm} / \mathrm{yr}$. However, the alongaxis depth varies significantly within our survey area (Figure 3). There is a long-wavelength gradient in axial depth such that the ridge becomes steadily deeper from $89^{\circ} \mathrm{E}$ to $116^{\circ} \mathrm{E}$.
Axial depths increase from $2300 \mathrm{~m}$ at $89^{\circ} \mathrm{E}$ to $4800 \mathrm{~m}$ at $116^{\circ} \mathrm{E}$. This overall eastward increase in axial depth is not monotonic. Transform faults appear to separate portions of the ridge axis which exhibit different along-axis depth gradients [Sempéré et al., 1997].

Mid-ocean ridge axial topography can be considered as the sum of a regional component describing the basic shape of the ridge axis and a local component resulting from local 


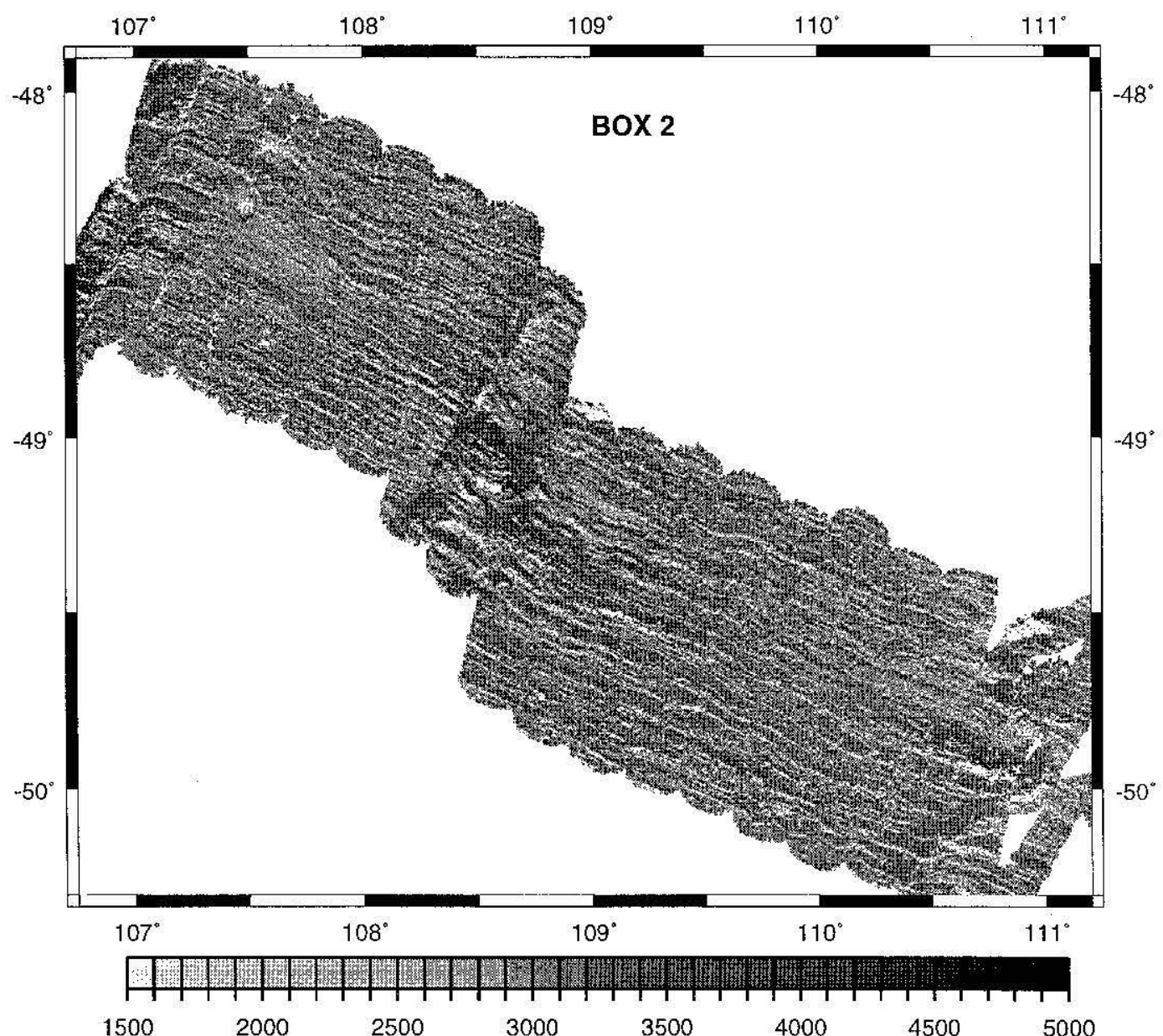

Figure 2b. Shaded relief SeaBeam bathymetric maps for survey area denoted box 2. Map is illuminated from the north in order to emphasize the abyssal hill fabric on the ridge flanks.

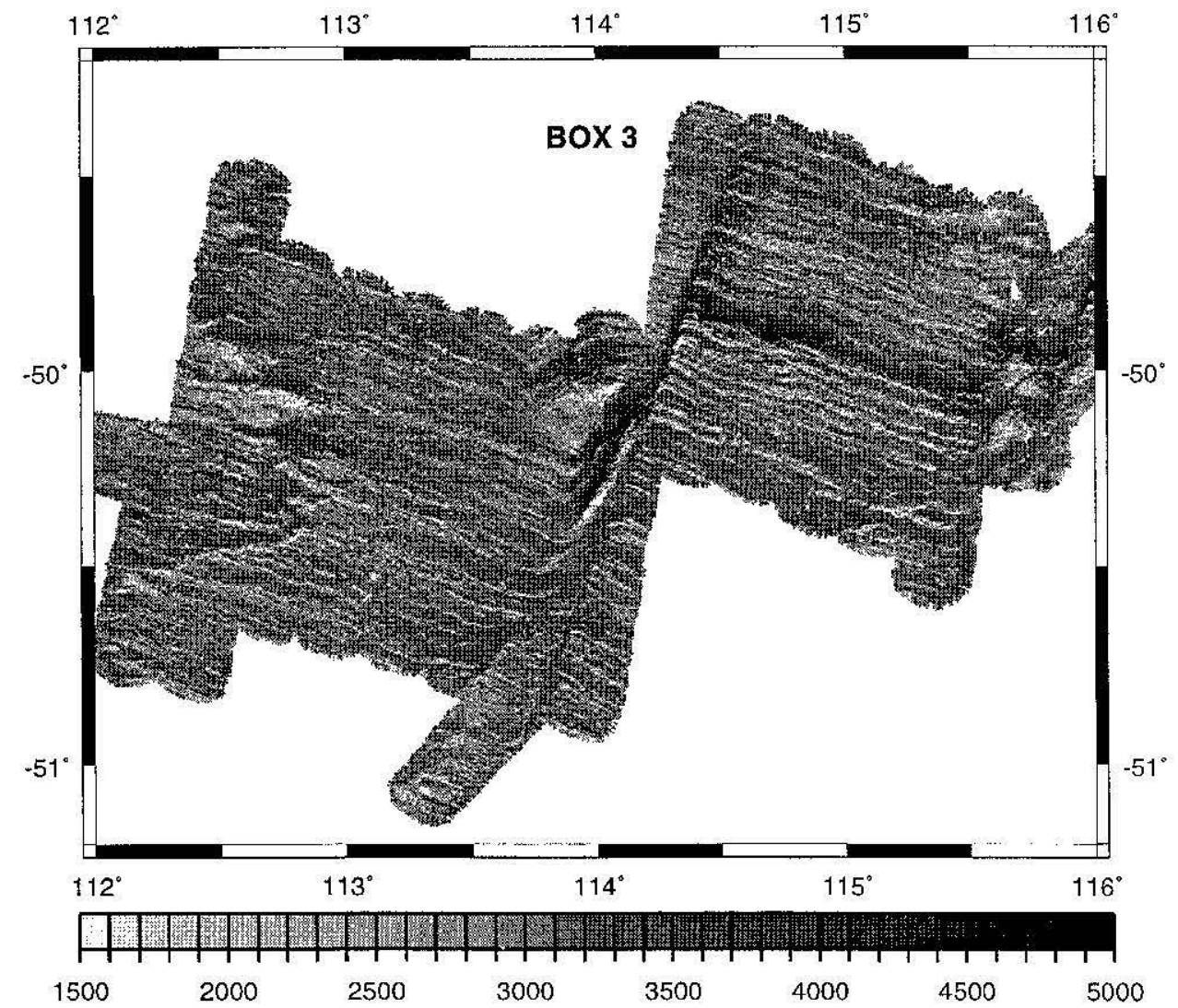

Figure 2c. Shaded relief SeaBeam bathymetric map for survey areas denoted box 3. Map is illuminated from the north in order to emphasize the abyssal hill fabric on the ridge flanks. 


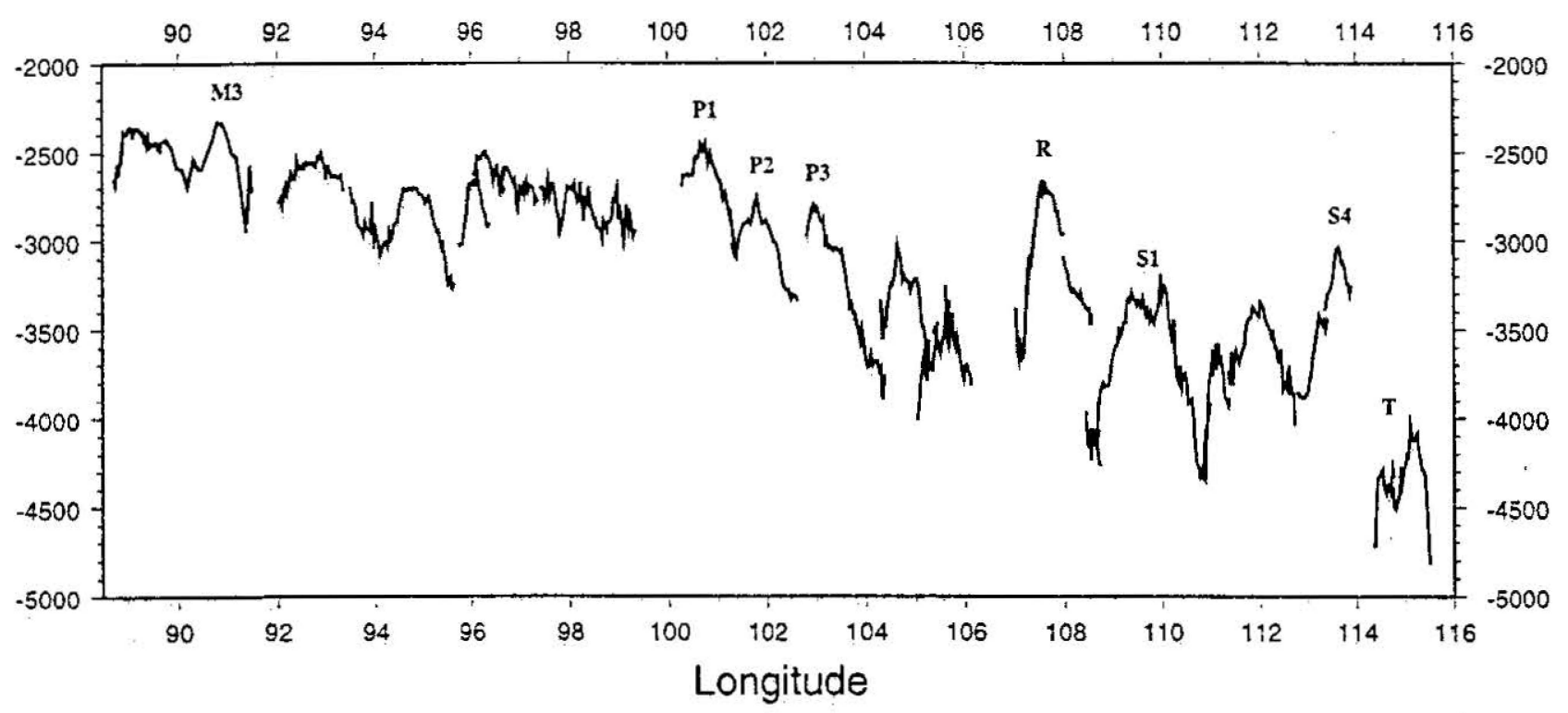

Figure 3. Along-axis depth between $88^{\circ} \mathrm{E}$ and $116^{\circ} \mathrm{E}$ on the SEIR. Segments within the detailed survey boxes are identified as on Figure 1.

topographic relief. The clearest examples of regional components are the gradual increase in depth away from the ridge axis and the basic forms of the axial morphology (i.e., axial highs and axial valleys), since these features repeatedly occur from profile to profile and have a relatively consistent form. They represent fundamental features of mid-ocean ridges. In contrast, most small features such as abyssal hills and seamounts are not repeatedly found from profile to profile and can be regarded as stochastic "noise" superimposed on the first-order variations of ridge axis topography. These features can be considered as local components. Both the regional component and local component result from magmatic, tectonic, and thermal processes involved in the creation of new crust. The two components contain different information on crustal generation and separating the two components from each other provides a basis for identification of types of axial morphology, determination of bathymetric roughness, and analysis of the processes responsible for crustal genesis.

In this study, the empirical orthogonal function (EOF) analysis adapted by Small [1994] for bathymetric data is used to separate the regional component of ridge morphology from the local component. An EOF analysis decomposes a twodimensional (2-D) data field into orthogonal modes or basis functions which span one dimension of the data space while providing information on the amplitude of the modes in the other dimension. The process can be thought of as somewhat analogous to decomposing a function into a series of Fourier coefficients. We will briefly outline the method here. Detailed discussions are given in Lorenz [1959], Davis [1976], Menke [1989] and Small [1994].

We consider a 2-D topographic field $D(\nu, x)$, which varies as a function of distance $x$ perpendicular to the axis. We wish to represent this field as a linear combination of orthogonal spatial modes $M(x)$ and the coefficients defining the amplitude of these modes $C$. The coefficients $C$ will, in general, be a function of position $s$ along the axis. Thus

$$
D\left(s_{i}, x_{j}\right)=\sum_{\mathrm{k}=1}^{\mathrm{N}} C_{k}\left(s_{i}\right) M_{k}\left(x_{j}\right)
$$

The problem can be written as a matrix equation and factored using a singular value decomposition [e.g., Menke, 1989] as

$$
D=U S V^{T}
$$

where $U$ and $V$ are orthogonal matrices and $S$ is a diagonal matrix of singular values. Thus the factorization shown in (1) can be obtained from the singular value decomposition in (2) if $C=U S$ and $M=V^{T}$. An individual bathymetric profile can then be described as a linear combination of independent spatial modes:

$$
D(x)=c_{1} M_{3}(x)+c_{2} M_{2}(x)+\ldots+c_{r} M_{r}(x)+R(x)
$$

where $M_{1}, M_{2}, \ldots, M_{r}$ are the spatial modes $c_{1}, c_{2}, \ldots, c_{r}$ are the individual coefficients for this profile, $r$ is the number of significant modes making up the regional portion of the profile, and $R(x)$ is the sum of the remaining modes. The spatial modes $M_{k}$ provide estimates of the dominant forms of the ridge structure, while the coefficients $C(x)$ give an estimate of how the independent modes combine to form the ridge morphology for a particular profile. Because the local component often contains small seamounts which are generally not normally distributed, the median absolute deviation (MAD) is used as the estimates of bathymetric roughness [Small, 1994]. The EOF analysis also provides an estimate of axial relief, which is defined as the range of linear combinations of the modes used to determine the regional component.

To apply the EOF analysis to our survey areas, bathymetric profiles were extracted every $2 \mathrm{~km}$ along the ridge axis from bathymetric data gridded at a $0.2 \mathrm{~km}$ spacing in the four survey boxes. Profiles containing large seamounts were excluded. The extracted profiles were then sampled at a $1 \mathrm{~km}$ interval using an Akima Spline and were cut to a constant length of 40 $\mathrm{km}$ on each side of ridge axis. In order to eliminate any bias resulting from the directional orientation [Small, 1994], the 581 extracted profiles were included in both forward and reversed orientation in the EOF analysis. 


\section{Results}

Distribution of Singular Values and Primary Modes from the EOF analysis

The normalized singular values $S(j)$ obtained from the EOF analysis at the SEIR show a distinct break between the first four singular values and the higher-order singular values. Approximately $30 \%$ of the variance in topographic signal at the ridge axis can be represented in terms of the these four modes (Figure 4a).

The primary modes $M(x)$ and their corresponding coefficients $C(v)$ from the SEIR are shown in Figure $4 \mathrm{~b}$. For comparison, an EOF analysis from a global data set [Small, 1994] is shown in Figure 4c. While the primary modes determined from the global study have two distinct modes corresponding to an axial valley and an axial high (global mode 1 and global mode 2, Figure $4 \mathrm{c}$ ), our data have only one mode which represents either an axial high when multiplied by a positive coefficient or an axial valley when multiplied by a negative coefficient (Figure $4 \mathrm{~b}$ ). This difference probably occurs because the global data set is dominated by welldeveloped end-member morphologies which each impose their own distinct primary modes, while the SEIR data set is dominated by "rifted" axial highs and shallow axial valleys which could not be separated into two clear modes. Actually, our mode 1 appears to be a compromise between global mode 1 and mode 2. Our mode 2 is not found in the global data set and is unique to the SEIR. It has positive coefficients at both axial highs and axial valleys and appears to modify the shape of mode 1 . When combined with mode 2 , the flanking low of mode 1 will be reduced at axial highs but will be augmented as a high at axial valleys to form the rift mountains. Mode 3 represents a monoclinal antisymmetric component. It has larger values at axial valleys, particularly near propagating rifts where inner pseudofaults create high blocky morphology asymmetrically distributed about the ridge axis. Mode 4 also represents an antisymmetric component but with much less importance than the first three components, as indicated by its small singular value which is only slightly larger than the higher modes and near-zero coefficients for almost all segments. It appears to help in describing large-amplitude blocky morphology found at a few locations (Figure 4b).

The primary modes from our study account for only $30 \%$ of the variance in lopography, compared to $46 \%$ of the variance in topographic signal represented by the primary modes in the global analysis. This can be attributed to the relatively lower relief of the SEIR axial morphology compared with the global data set and the low axial relief relative to the stochastic morphology of the SEIR. Although the first four modes account for only $30 \%$ of variance in topographic signal, they generally represent the basic shape of axial morphology very well. The regional component determined by the first four modes and the local component determined by the remaining modes are shown in Figure 5. Along-axis axial relicf and bathymetric roughness are shown in Figure $6 a$ and Figure $6 \mathrm{~b}$, respectively.

\section{Regional Component}

The axial morphology on the SEIR between $88^{\circ} \mathrm{E}$ and $118^{\circ} \mathrm{E}$ shows a general evolution from axial highs in the west to a deep axial valley at the eastern end of the survey area. Three distinct types of axial morphology can be identified from the regional component (Figure 5): axial highs are found west of $102^{\circ} 45^{\prime} \mathrm{E}$, shallow axial valleys characterize the ridge axis between $104^{\circ} 45^{\prime} \mathrm{E}$ and $114^{\circ}$, and a deep "MAR-type" axial valley is found east of $114^{\circ}$. Segment P3, extending from $102^{\circ} 30^{\prime} \mathrm{E}$ to $104^{\circ} 30^{\prime} \mathrm{E}$ (Figure 2a), is a transitional segment. The segment is marked by a low, blocky, fault-bounded high at the west end of the segment which changes to an axial valley which broadens and deepens toward the east [Sempéré et al.,

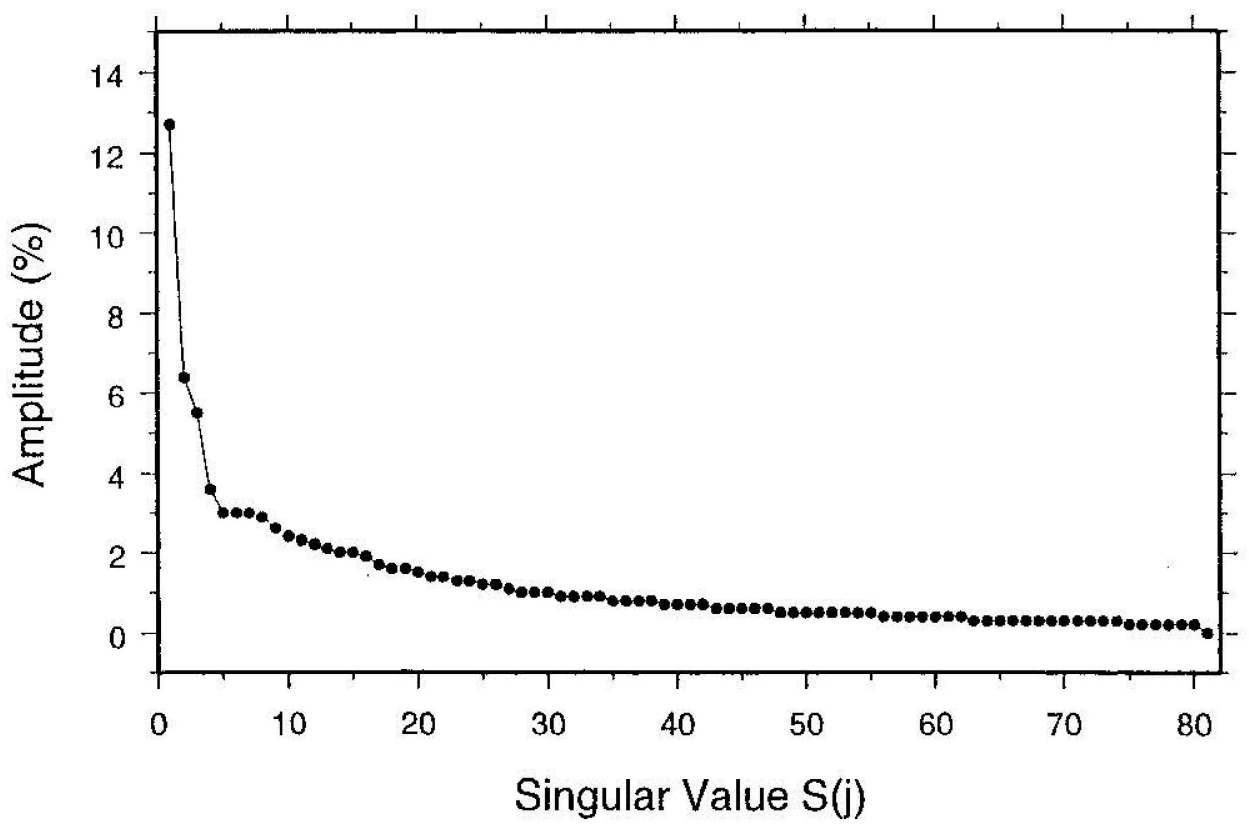

Figure 4a. The spectrum of singular values obtained from an empirical orthogonal function (EOF) analysis at the SEIR. The spectrum shows a distinct break between the first four singular values and the higher-order singular values. Approximately $30 \%$ of the variance in topographic signal at the ridge axis can be represented in terms of the these four modes. 


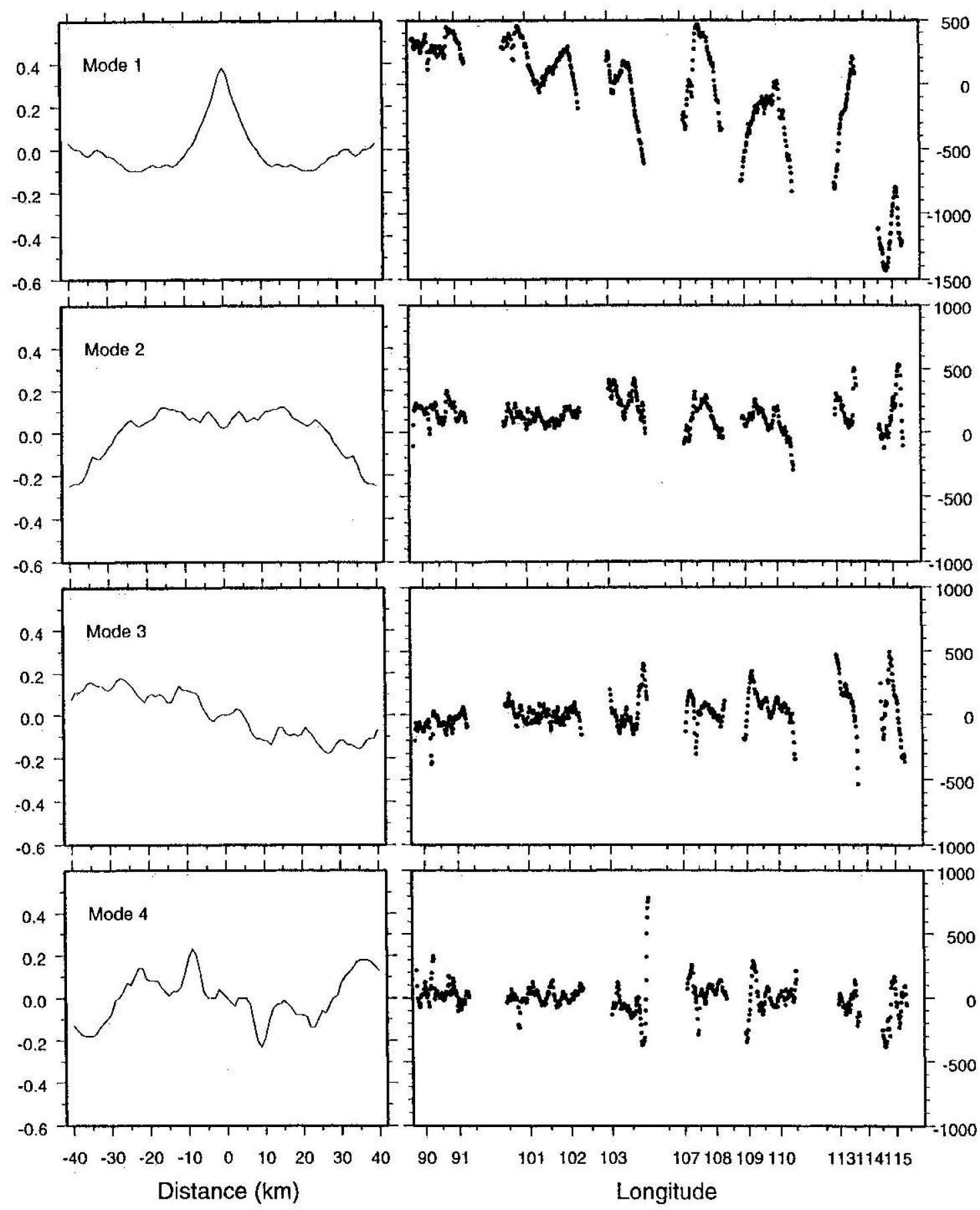

Figure 4b. The first four primary modes $M(x)$ and their corresponding coefficients $C(v)$ as function of longitude on the SEIR. Mode 1 appears to be a compromise shape between an axial high and an axial valley. Mode 2 appears to modify the shape of mode 1 . Mode 3 represents a monoclinal antisymmetric component, and mode 4 represents an antisymmetric component of much less importance than the first three modes.

1997]. Segment $R$ appears somewhat anomalous. For about $50 \mathrm{~km}$ in the central of the segment, the axis is formed by a linear volcanic ridge along the apex of a broad fault-bounded plateau (Figure 2b). The plateau becomes less distinct away from the center of the segment, and both ends of the segment are characterized by a shallow axial valley.

Typical bathymetric profiles representing the different types of axial morphology observed along the SEIR are shown in Figure 7. A well-defined triangular-shaped "EPR-type" axial high (Figure $7 \mathrm{a}$ ) is only found at a few locations on the SEIR.
This morphology is best displayed at segment P1. Otherwise, axial highs on the SEIR are "rifted highs" which are lower (150-250 $\mathrm{m}$ high) and less well defined and characterized by faults with throws of $50-100 \mathrm{~m}$ near the axis, often within about $1 \mathrm{~km}$ (Figure 7b). Both ends of segment P1 become more rifted, so that there is no clear boundary between the EPR-type axial high and rifted axial high and the two forms of axial high appear to grade into each other.

The shallow rift valleys are generally $10-15 \mathrm{~km}$ wide with $100-500 \mathrm{~m}$ relief, although they tend to become deeper near 

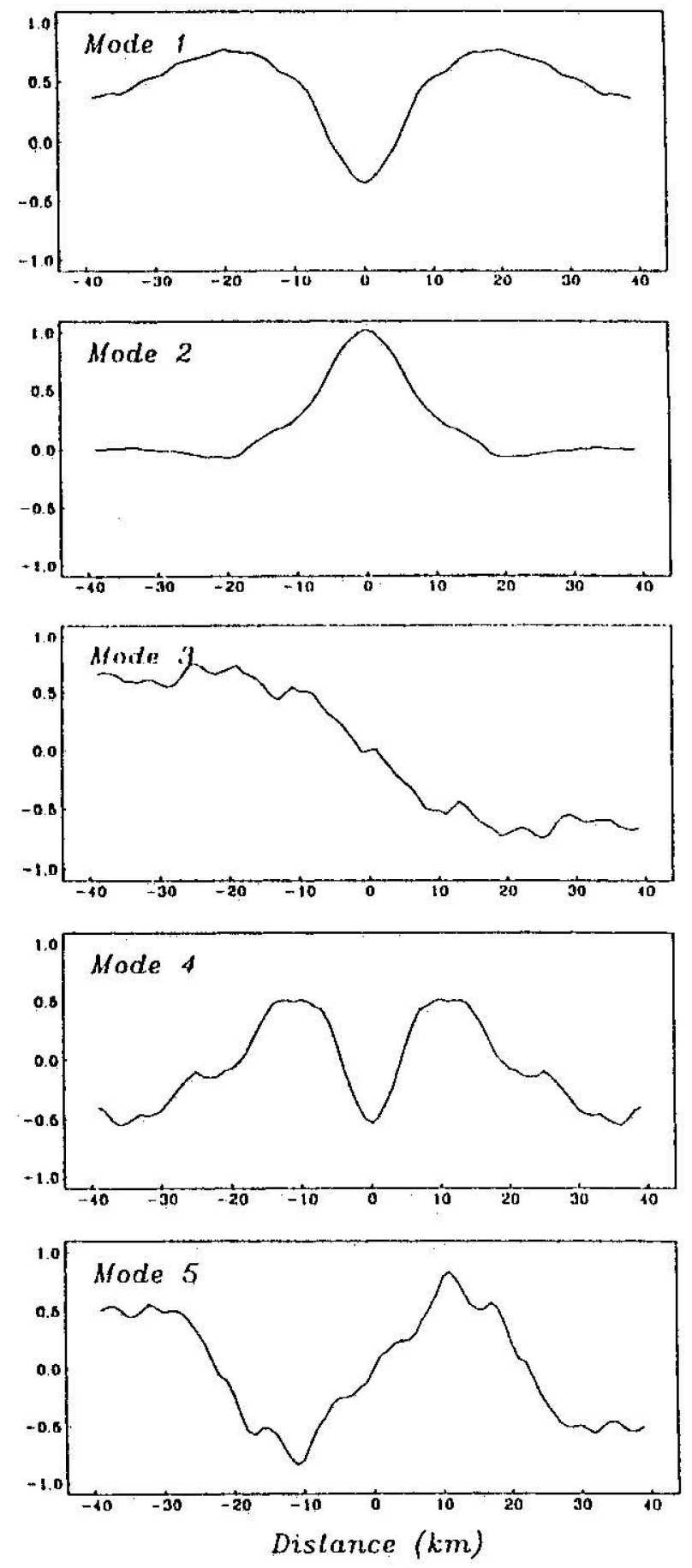

Figure 4c. The results of an EOF analysis of a global data set by Small (1994). Mode 1 and mode 2 resemble a slow and fast spreading ridge topography, respectively. Mode 3 is a monoclinal antisymmetric component. Mode 4 and mode 5 represent symmetric and antisymmetric components, respectively.

segment boundaries. In some cases, this deepening is related to the presence of propagating rifts which are common features of the SEIR (Figure 2) [Sempéré et al., 1997]. The MAR-type deep rift valley is $15-20 \mathrm{~km}$ wide with $1000-1500 \mathrm{~m}$ relief. Flanking uplifts found at the deep axial valley are not observed at the shallow rift valleys, even near segment ends and deeper portions. There is a distinct break in axial relief between these two forms of axial valley morphology.
There is an overall increase of $-2100 \mathrm{~m}$ in axial depth from $88^{\circ} \mathrm{E}$ and $118^{\circ} \mathrm{E}$ (Figure 3 ). This increase in depth is due to a combination of two components: a change in the nature and relief of the axial morphology (Figure 6a) and the actual change in ridge depth due to changes in mantle temperature and crustal thickness. To the extent that axial morphology is dynamically supported, the along-axis variations in depth due to changes in axial relief will disappear as the crust moves away from the ridge axis. Examination of the variations in off-axis depth therefore allows us to determine the variations in depth due to crustal thickness and/or mantle temperature. Along-strike, off-axis depth ( $10 \mathrm{~km}$ away from ridge axis) on both flanks of the ridge axis extracted from the regional component of the ridge topography is plotted in Figure 8 . The overall variation in off-axis depth is much smaller than alongaxis depth. Off-axis depth increases by only $500 \mathrm{~m}$ from $90^{\circ} \mathrm{E}$ to $116^{\circ} \mathrm{E}$, compared to the $2100 \mathrm{~m}$ increase in axial depth. The change in axial depth caused by variations in mantle temperature and crustal thickness thus accounts for only about $24 \%$ of the total variation in axial depth, and about $76 \%$ of the variation in axial depth may be attributed to the dynamically related axial relief.

There is little variation in off-axis depth within segments, except in segment $T$. In particular, the prominent depth minima associated with segment centers in along-axis depth largely go away in off-axis depth profiles, especially at segments with axial highs (Figure 3). These observations suggest that the intrasegment variation in crustal thickness is much smaller than would be predicted from along-axis depth variations and that the variations in ridge axis depth are mostly dynamicaily maintained. The variation in off-axis depth at segment $T$ with a deep axial valley has similar magnitude to the ridge axis depth, indicating that the variations in axial depth within this segment may be largely due to variations in crustal thicknoss.

\section{Local Component}

The local (stochastic) component of ridge morphology determined from the EOF analysis shows that flank morphology becomes rougher from west to east (Figure 5). The roughness of flank morphology increases as axial morphology changes from an axial high to a shallow rift valley and to a MAR-type rift valley. The variations in flank morphology can be seen clearly from the MAD roughness calculated from the stochastic component of the EOF analysis (Figure 6b). In general, along-axis bathymetric roughness roughly doubles across the survey area. However, this eastward increase in roughness is not uniform but occurs in distinct steps. A $t$ test statistical analysis shows that the roughness values fall into three groups from west to east. Segments west of $102^{\circ} 45^{\prime} \mathrm{E}$ with axial highs (M3, P1 and P2) fall into one group with low roughness values (mean $=38 \mathrm{~m}$ ); segments from $102^{\circ} 45^{\prime} \mathrm{E}$ to $114^{\circ} \mathrm{E}$ fall into a second group with intermediate values (mean $=61 \mathrm{~m}$ ). This group includes segments with shallow axial valleys ( $\mathrm{S} 1$ and $S 4$ ), a transitional segment $\mathrm{P} 3$ and an anomalous segment $\mathrm{R}$. The deep axial valley ( $\mathrm{T}$ ) falls into a third distinct group with higher values (mean $=87 \mathrm{~m}$ ). The mean roughness is significantly different between groups but is not significantly different within groups with a confidence level of $>99 \%$ as shown by an $F$ test. There is no significant change in roughness between EPR-type axial highs and rifted axial highs. The sharp changes in flank morphologic roughness 


\section{Regional Component}

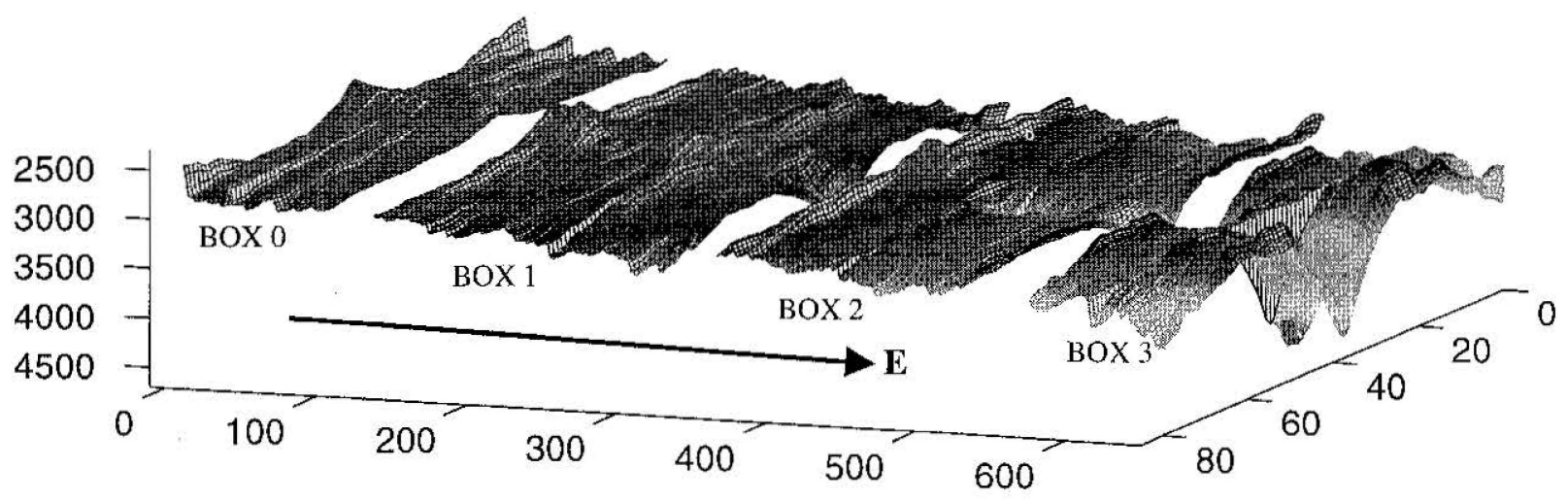

Local Component

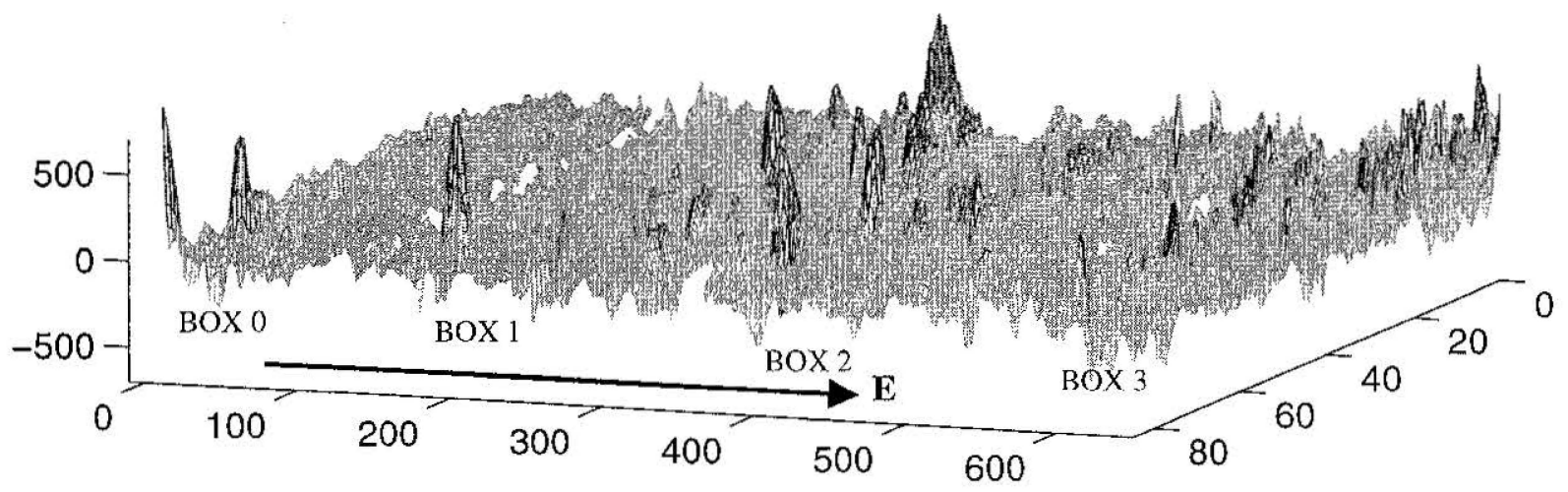

Figure 5. (top) The regional component determined by the first four modes and (bottom) the local component determined by the remaining modes from the EOF analysis. Axial morphology on the SEIR between $89^{\circ} \mathrm{E}$ and $116^{\circ} \mathrm{E}$ undergoes an evolution from an axial high in the west to a deep axial valley in the east as shown in the regional component. The local component of ridge morphology shows that flank morphology becomes rougher from west to cast.

corresponding to different types of axial morphology observed in our new data are consistent with previous studies based on old, sparse bathymetric data [Ma and Cochran, 1996], except that the abrupt nature of the change is much more obvious in the new data.

Compared with roughness estimates from the global EOF analysis of mid-ocean ridges [Small, 1994], the axial high group at the SEIR falls in the lower range of the Pacific group, while the deep rift valley group at the SEIR falls in the lower range of the Atlantic group. The group with intermediate values lies between the Pacific and the Atlantic group. The SEIR thus not only has ridge flank morphologic characteristics similar to these found at fast and slow spreading ridges but also has an unique ridge flank morphology characteristic of intermediate spreading ridges.

The step changes in roughness values between the three groups are also accompanied by a change in the variability of the roughness within segment. The variability in roughness within segments increases steadily from the axial high group (standard deviation in the range of 6.9-10.7 m) to the deep valley group (standard deviation in the range of $12.0-16.5 \mathrm{~m}$ ).

In addition to the regional-scale variations in ridge flank roughness related to the form of the axial morphology, systematic segment-scale variations are also observed (Figure 6b). Roughness shows a V-shaped pattern within segments for segments with axial highs, with the lowest values occurring near the segment center and larger values occurring at the segment ends. No such clear pattern is observed at segments with axial valleys. Roughness changes irregularly within axial valley segments though larger values are associated with segment ends. As a result, roughness is well correlated with axial depth within segments with axial highs but is correlated poorly with axial depth at segments with axial valleys (Figure 9).

The obvious implication of the difference in roughness between axial highs and axial valleys is that there are different mechanisms for the generation of roughness (abyssal hills) at segments with axial highs and axial valleys. The V-shaped patterns observed from bathymetric roughness are also found in RMS heights [Goff et al., 1997] calculated using the technique of Goff and Jordan [1988]. Goff et al. [1993, 1995] suggested that RMS height is generated primarily by normal faulting near the ridge axis. If this is true, then the V-shaped pattern in roughness and RMS height at axial highs implies that there is an association of small-throw faults with weaker lithosphere (higher axial temperatures) near segment centers and large-throw faults at segment ends.

Previous studies suggested that magnetic anomaly amplitude 


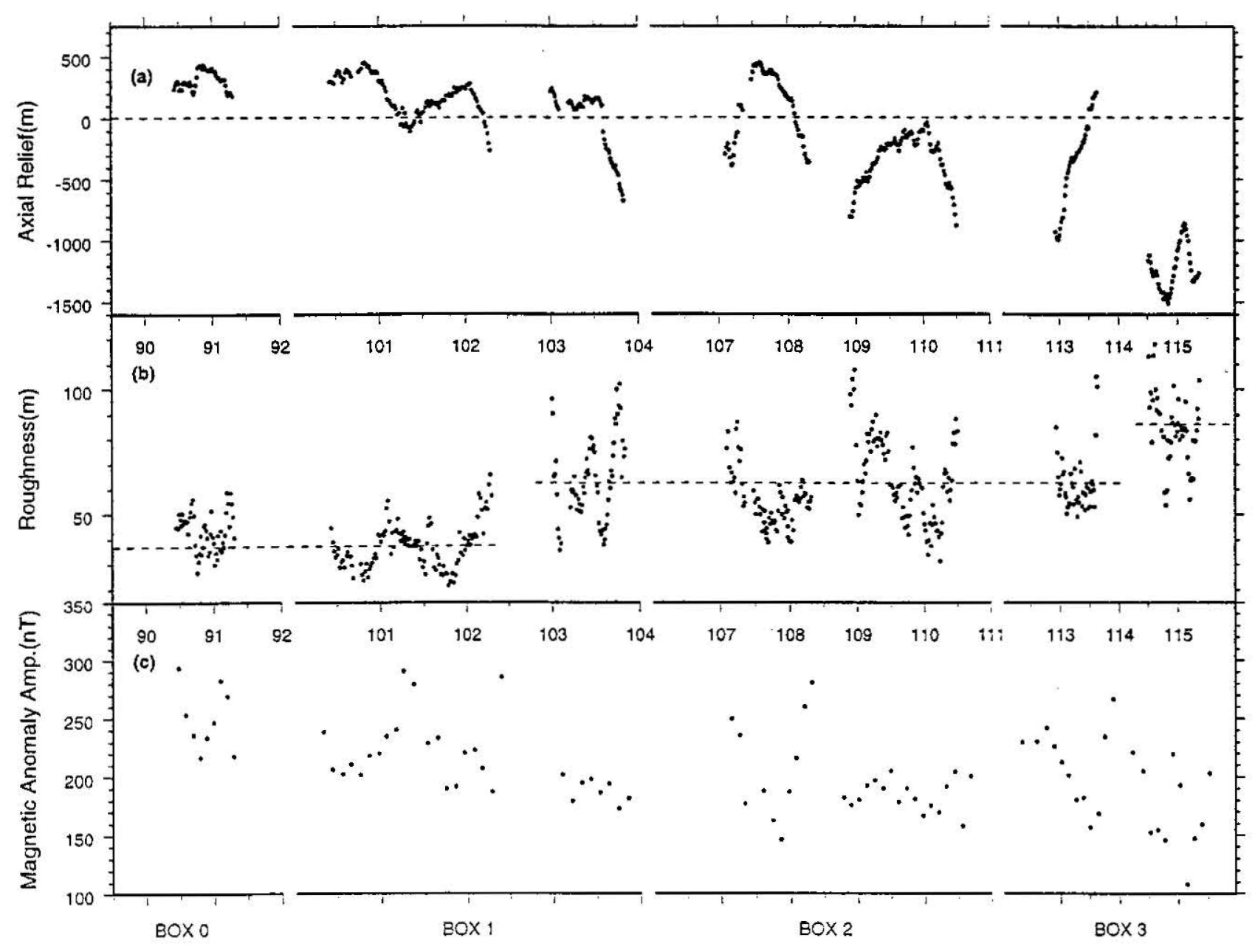

Figure 6. (a) Axial relief, (b) bathymetric roughness, and (c) magnetic anomaly amplitude for the eight segments in the detailed survey boxes. Axial relief is defined as the range of linear combinations of the modes used to determine the regional component. It shows a strong correlation with axial depth. Roughness, determined as the median absolute deviation (MAD) of the local component, increases in a step-like manner from west to east. Magnetic anomaly amplitude, estimated as the standard deviation about the mean within 40 $\mathrm{km}$ of the ridge axis, decreases from $89^{\circ} \mathrm{E}$ to $103^{\circ} \mathrm{E}$ and remains nearly constant from $103^{\circ} \mathrm{E}$ to $115^{\circ} \mathrm{E}$.

also changes with axial morphology and flank morphology [Cochran, 1991; Ma and Cochran, 1996]. The magnetic anomaly amplitude estimated as the standard deviation about mean within $40 \mathrm{~km}$ of the ridge axis using our new data is plotted in Figure 6c. Magnetic anomaly amplitude generally decreases from $89^{\circ} \mathrm{E}$ to $103^{\circ} \mathrm{E}$ and then remains nearly constant from $103^{\circ} \mathrm{E}$ to $115^{\circ} \mathrm{E}$. Within segments, V-shaped patterns in magnetic anomaly amplitude are clearly observed at segments $\mathrm{M} 3$ and $\mathrm{P} 1$ with vigorous axial highs and at segment $\mathrm{R}$ with an anomalous axial high but not at other segments, including segment P2 with a rifted axial high.

\section{Discussion}

\section{Along-Axis Depth and Off-Axis Depth}

The large variations in both regional-scale and segmentscale axial depth are not observed in off-axis depth. Off-axis depth increases gently from west to east by about $500 \mathrm{~m}$ (Figure 8) in contrast to the $2100 \mathrm{~m}$ change in axial depth. It has been suggested that the ridge axis topography at axial highs is supported by a low-density region beneath the ridge axis which exerts an upward buoyant force at the ridge axis [e.g., Madsen et al., 1984; Wang and Cochran, 1993] and that axial valley ridge axis topography results from horizontal extensional stresses in a thickening lithosphere [e.g., Phipps Morgan et al., 1987]. The variation in axial depth thus results from both changes in the nature and relief of the axial morphology supported by these axis-related forces and the actual change in ridge depth due to the changes in mantle temperature and crustal thickness. Any dynamic contribution to the variations in axial depth will be greatly reduced as the crust migrates to the ridge flank, and off-axis depth variations thus primarily reflect variations in crustal thickness and mantle temperatures at the time of the accretion.

If we assume that the melt production rate remained constant over the past $\sim 0.26 \mathrm{~m}$.y., the variation in off-axis depth at 10 $\mathrm{km}$ away from the ridge axis indicates that the regional variation in crustal thickness from west to east between $89^{\circ} \mathrm{E}$ and $116^{\circ} \mathrm{E}$ on the SEIR is much smaller than would be predicted from axial depth. If the $500 \mathrm{~m}$ difference in off-axis depth is due completely to changes in crustal thickness, $\sim 2 \mathrm{~km}$ difference in crustal thickness is required by isostasy. It thus appears that a major portion of the regional variation in axial 

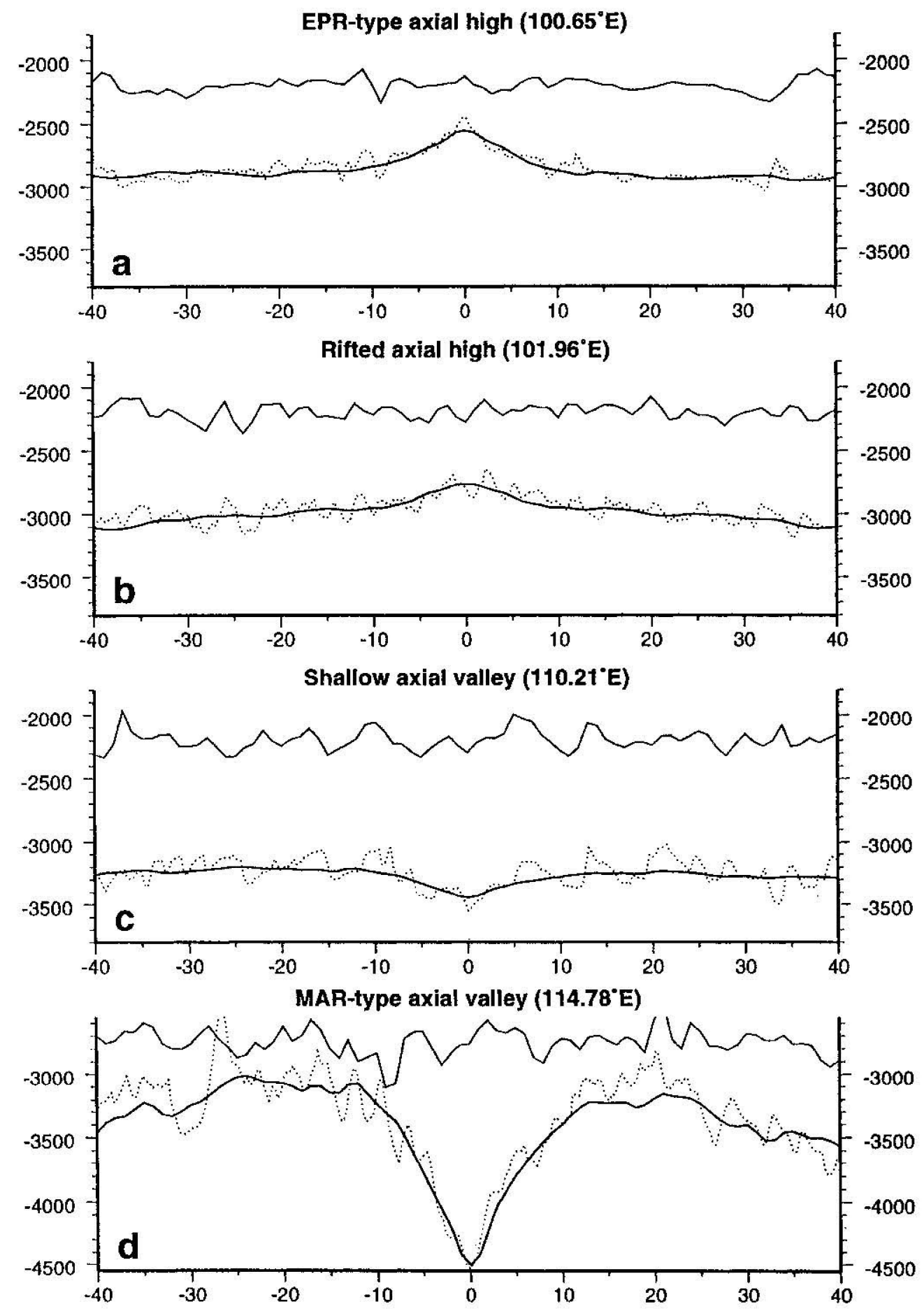

Figure 7. Typical regional topographic profiles representing the range of axial morphology observed on the SEIR. The observed profile and regional profile are indicated by a dotted line and a thick solid line, respectively. The thin solid line at the top is roughness. (a) The EPR-type axial high is characterized by a $250-400 \mathrm{~m}$ relief, $15-20 \mathrm{~km}$ wide, well-defined triangular-shaped high, while (b) the rifted axial high is characterized by a broader, lower $150-250 \mathrm{~m}$ relief high. Inward facing faults are found almost immediately at the ridge axis. (c) The shallow rift valleys are generally $10-15 \mathrm{~km}$ wide with $100-500 \mathrm{~m}$ relief and (d) the MAR-type deep rift valley is $15-20 \mathrm{~km}$ wide with $1000-1500$ m relief.

depth results from changes in the amplitude of the dynamically supported axial relief and that changes in crustal thickness and mantle temperature contribute much less to the variation in axial depth.

The several hundred meters variation in axial depth within each segment is also significantly reduced in off-axis depth, except at segment $T$ with a deep axial valley which shows a variation in off-axis depth comparable to that in the axial depth. Except at segment $\mathrm{T}$, the small variation in off-axis depth implies that the larger intrasegment variations in axial depth are primarily associated with ridge axis processes and are not carried away from the ridge axis with the seafloor. The 


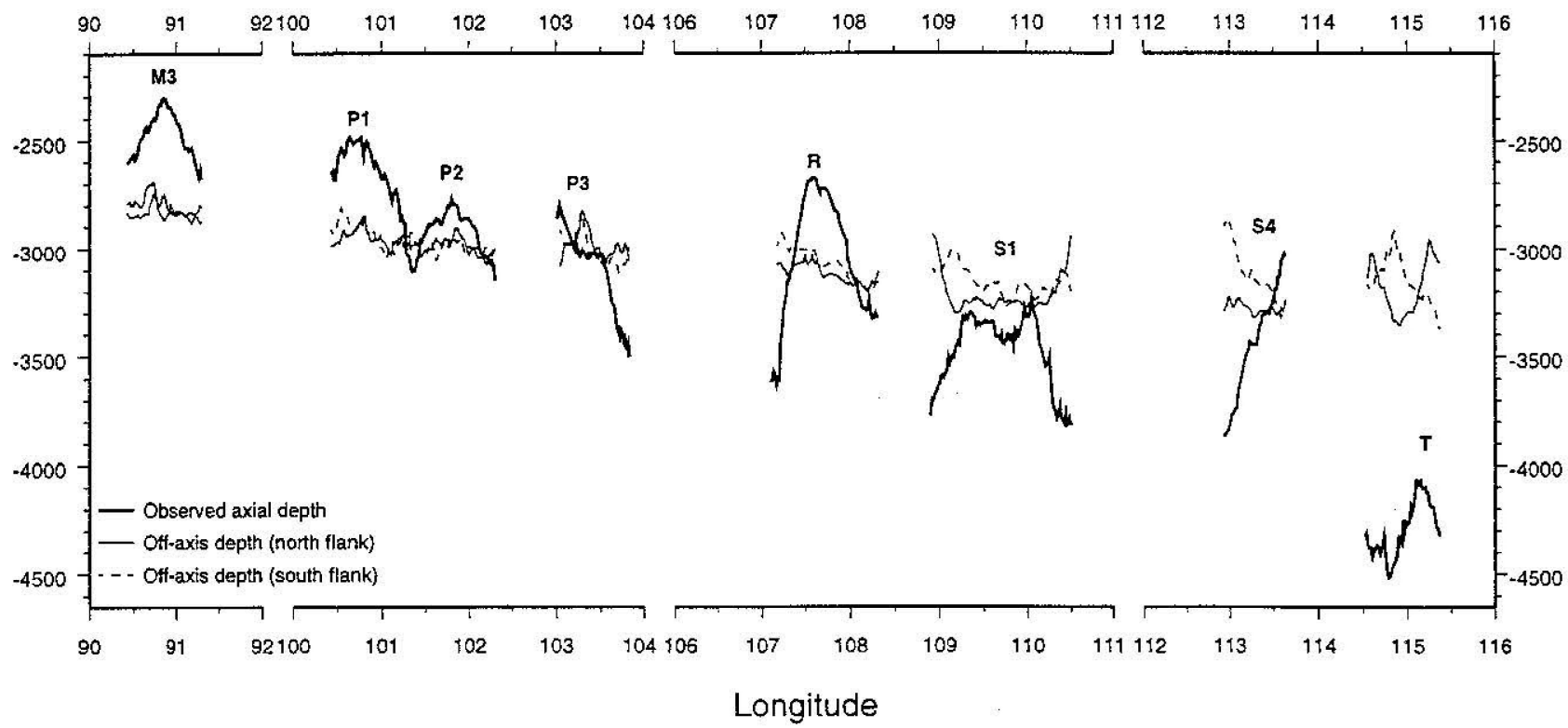

Figure 8. Along-axis depth (thick solid line) and along-strike off-axis depth (10 km away from ridge axis) on the north flank (thin solid line) and the south flank (dashed line) of the ridge axis extracted from the regional component of the ridge topography. The overall variation in off-axis depth is much smaller than along-axis depth. Off-axis depth increases by only $500 \mathrm{~m}$ from $90^{\circ} \mathrm{E}$ and $116^{\circ} \mathrm{E}$, compared to the $2100 \mathrm{~m}$ increase in axial depth.

nearly flat off-axis depth profiles at axial highs and shallow axial valleys indicate that there is much less variation in crustal thickness within these segments than would be expected from intrasegment axial depth variation. For example, there is only $\sim 100 \mathrm{~m}$ variation in off-axis depth at segment $\mathrm{P} 1$, compared to $\sim 500 \mathrm{~m}$ variation in axial depth. Crustal thickness variations within segment P1 thus appear to contribute at most $20 \%$ of the $500 \mathrm{~m}$ variation in axial depth at this segment.

Segment $T$ has a deep axial valley with an axial depth range from $4000 \mathrm{~m}$ to $4800 \mathrm{~m}$, similar to the depths found at the MAR. The changes in axial depth within segment $T$ are similar to the variations on off-axis depth, implying that they are probably caused by changes in crustal thickness as suggested by Neumann and Forsyth [1993] for the slow spreading southern MAR.

The humped shapes in axial depth within segments with axial highs must be primarily supported by upward buoyant forces associated with low density at the ridge axis which must be focused near the segment center [Macdonald and Fox, 1988]. Gravity studies at fast spreading ridges suggest that the upwelling of partial melt is concentrated in the central portion of ridge segments [Wang and Cochran, 1993; Wang et al, 1996]. Magma chambers, which are commonly observed at fast spreading ridges, may allow melt to redistribute along axis, resulting in small variations in crustal thickness [Wang and Cochran, 1993]. If a magma chamber is present beneath axial highs at the SEIR, then it may allow redistribution of melt along axis, explaining the small variation in off-axis depth observed at this segment. Even if a steady state magma chamber is absent at segments with rifted highs and shallow axial valleys, the lower crust may be hot and weak and thus unable to support variations in crustal thickness [Bell and $B u c k, 1992]$. This could lead to along-axis flow of the lower crust to eliminate crustal thickness variations, resulting in little variation in off-axis depth at these segments.

\section{Implications of Abrupt Changes in Roughness}

One important result of our quantitative analysis of flank morphology is that we recognize two eastward step-like increases in roughness corresponding to the morphologic transitions from an axial high to a shallow axial valley and from a shallow axial valley to a deep axial valley. It has been suggested that abyssal hills are generated primarily by faulting near the ridge axis. Bathymetric roughness therefore largely reflects the size of the normal faults bounding abyssal hills. The size of these faults is controlled by the lithospheric strength of the ridge axis. The step increases in roughness across our survey area thus imply that the strength of lithosphere increases abruptly as axial morphology changes from one mode to another mode.

Phipps Morgan and Chen [1993a] have argued that the presence or absence of a crustal magma chamber is a threshold phenomenon which has a large effect on the temperature structure and the strength of the crust and upper mantle. This is due to a feedback mechanism in which the latent heat released by freezing of the lower crust within the melt lens tends to encourage formation of an even shallower melt lens. Below some critical melt supply (crustal thickness), a crustal melt lens can not be maintained, and this mechanism cannot function. Phipps Morgan and Chen [1993a] calculate that this can lead to major change in the thermal structure and that the depth to the solidus can increase by several kilometers as the result of a small change in crustal thickness across this threshold.

The transition from an axial high to an axial valley and the accompanying change in bathymetric roughness could both result from this (or similar) mechanism. An axial high is considered to result from the upward flexure of weak axial lithosphere by low-density asthenosphere beneath the axis [Madsen et al., 1984; Kuo et al., 1986; Wang and Cochran, 1993]. The gradient in asthenospheric temperature along the 

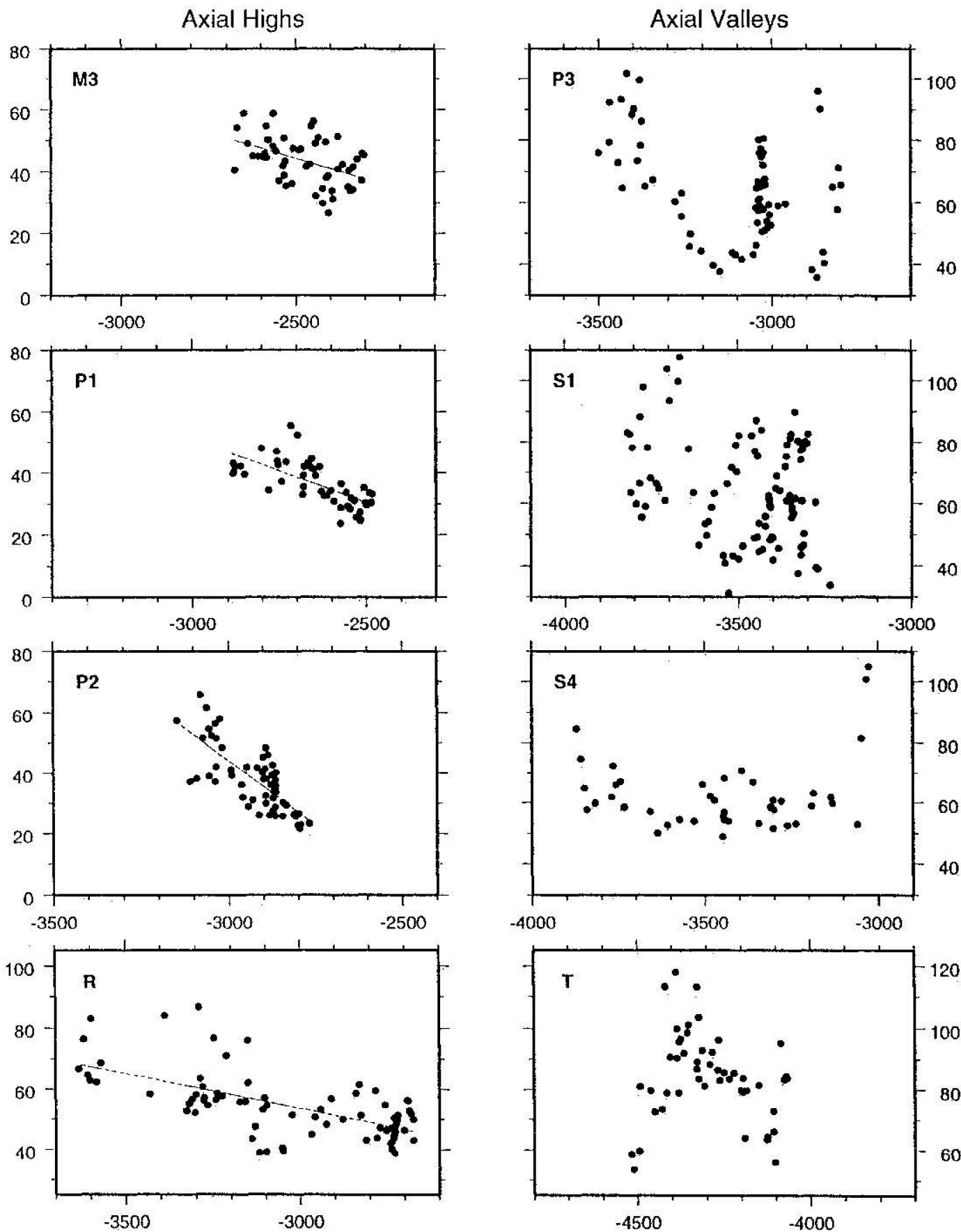

Figure 9. Axial depth versus bathymetric roughness for each segment. The relationship between axial depth and roughness varies at axial highs and axial valleys. Roughness is well correlated with axial depth (and thus with axial relief) within segments with axial highs but is poorly correlated with axial depth at segments with axial valleys.

SEIR and the resulting decrease in melt supply mean that at some point the threshold is reached and a crustal magma lens cannot be maintained. The resulting increase in lithospheric strength suppresses the flexure responsible for the axial high and allows larger faults to form causing the observed step in bathymetric roughness (Figure 6b).

\section{Different Patterns in Roughness Between Axial Highs and Axial Valleys}

In addition to the step change in roughness associated with the change from an axial high to an axial valley, different intrasegment patterns in roughness are observed for segments with axial highs and with axial valleys (Figures 6 and 9). Roughness estimates associated with axial highs are generally correlated well with axial depth and show V-shaped segmentscale variations, while roughness is correlated poorly with axial depth and shows no clear $\mathrm{V}$-shaped patterns at axial valleys. Goff [1991] and Goff et al. [1993, 1995] have found that abyssal hill RMS height tends to be largest toward the ends of segments and smallest toward the middle of segments at the EPR, but there is no such clear pattern associated with segments at the MAR. Our results are consistent with these observations from the EPR and the MAR in that V-shaped 
patterns in abyssal hills are generally associated with axial highs but not axial valleys, regardless of spreading rate.

The striking differences between axial high and axial valley may be due to the presence or absence of a magma chamber. It appears that there is a correlation between axial highs and the existence and depth of magma chamber [Purdy et al., 1992; Phipps Morgan et al., 1994]. Seismic studies suggest that continuous steady-state magma chambers exist at shallow, about $1.5 \mathrm{~km}$, depths beneath fast spreading ridges where axial highs are observed [Detrick et al., 1987; Mutter et al., 1995] but are not present beneath slow spreading ridges where axial valleys are present [Purdy and Detrick, 1986; Detrick et al., 1990], suggesting that magma chambers are transient features on slow spreading ridges. Magma chambers are also found at intermediate-rate Juan de Fuca and Valu Fa ridges, where rifted axial highs exist [Morton and Sleep, 1985; Morton et al., 1987; Rohr et al., 1988; Collier and Sinha, 1990], but at a deeper depth than at the EPR. Furthermore, a recent seismic refraction experiment conducted on the SEIR in the AustralianAntarctic Discordance (AAD) and east of the AAD indicate the presence of an axial magma chamber at segments with an EPRtype axial high to the east of the AAD and the absence of an magma chamber at segments with an axial valley in the AAD [Tolstoy et al., 1995].

The correlation between axial highs and the existence of magma chambers may explain the intrasegment variations in roughness in our study area. The steady depth gradient along the SEIR implies warmer asthenosphere and hence greater magma supply to the west. The humped shapes within segments in the axial depth suggest that a magma chamber may be formed near the segment center at these segments, resulting in weaker axial lithosphere near the center of the segment relative to the segment ends. Roughness will decrease with the decreased strength of the axial lithosphere toward the segment center, explaining the V-shaped pattern in roughness observed at axial highs. The rifted axial highs at the SEIR may indicate that the magma chambers in these areas are deeper as observed on the Juan de Fuca Ridge [Morton et al., 1987; Rohr et al., 1988]. A magma chamber is probably ephemeral at shallow axial valleys and may not be formed at deep valleys on the SEIR because of the cooler mantle temperature and lower magma supply.

\section{Conclusions}

1. Three distinct types of axial morphology were identified from the regional component of topography in our area: axial highs which may be EPR-type or rifted (segments M3, P1, and P2), shallow axial valleys (segments $S 1$ and S4), and MARtype deep axial valley (segment $\mathrm{T}$ ).

2. Axial depth increases by $\sim 2100 \mathrm{~m}$ from $88^{\circ} \mathrm{E}$ and $118^{\circ} \mathrm{E}$ on the SEIR, while off-axis depth shows only $\sim 500 \mathrm{~m}$ increase from west to east. There is little change in off-axis depth within segments except for segment $\mathrm{T}$ with a deep axial valley, in contrast to the large intrasegment variations in axial depth. These observations suggest that both the regional and intrasegment variations in crustal thickness are much smaller than would be predicted from variations in axial depth and that the major portion of the variation in ridge axis depth results from changes in the form of the dynamically supported axial morphology. The disappearance of the humped shapes which are observed in axial depth within segments from the off-axis depth may be attributed to the along-axis redistribution of material beneath the segments.
3. There are step-like increases in bathymetric roughness as the axial morphology changes from an axial high to a shallow axial valley and from a shallow axial valley to a deep axial valley. However, there are no significant changes in roughness between EPR-type axial highs and rifted axial highs. It appears that the EPR-type axial high and rifted axial high grade into each other, while axial highs, shallow axial valleys, and deep axial valleys are three distinct different forms of axial morphology on the SEIR. The step changes in roughness imply that the strength of the lithosphere increases abruptly as axial morphology changes from one mode to another mode. The abrupt changes in the strength of the lithosphere could be threshold effects resulting from gradual changes in crustal thickness with temperature [Phipps Morgan and Chen, 1993a]. As the magma supply decreases from west to east with the decrease in mantle temperature, it may reach a point where the lithospheric strength is very sensitive to small fluctuations in crustal input so that an abrupt transition occurs from a shallow steady state magma lens to no steady state magma lens. This change in crustal structure will result in a marked increase in lithospheric strength which will suppress the upward flexure responsible for the axial high and permit larger abyssal hill faults to form.

4. Systematic intrasegment variations in roughness are also observed in our area. Roughness shows V-shaped patterns within segments with axial highs but no clear patterns at segments with axial valleys. The different patterns in roughness at axial highs and axial valleys on the SEIR may be due to the presence or absence of a magma chamber. The along-axis depth gradient implies higher temperatures and greater magma supply and hence the existence of a magma chamber near the segment centers in the west portion of our survey area, resulting in wcaker axial lithosphere and hence lower roughness near the center of segment relative to the segment ends. The rifted axial highs may indicate that the magma chambers in these areas are deeper or are not in steady state. A magma chamber is probably ephemeral at shallow axial valleys and may not be formed at deep valleys on the SEIR.

Acknowledgments. We would like to thank Captain E. Buck and the crew and the scientists of R/V Melville cruise for their assistance in collection of the high quality data used in this paper. Christopher Small provided valuable advice in the EOF analysis and a thoughtful review of the manuscript. The GMT software package of Paul Wessel and Walter Sinith was used extensively in the preparation of this paper. This research was supported by National Science Foundation grant OCE9302091. Lamont contribution number 5670 .

\section{References}

Bcll, R. E., and W. R. Buck, Crustal control of ridge segmentation inferred from observations of the Reykjanes Ridge, Nature, 357, 583$586,1992$.

Chen, Y. J., and W. J. Morgan, Rift valley/no rift valley transition at midocean ridges, $J$. Geophys. Res., 95, 17,571-17,581, 1990

Cochran, J. R., Systematic variation of axial morphology along the Southeast Indian Ridge (abstract), Eos Trans. $A G U, 72(17)$, Spring Meet. Suppl., 260, 1991

Cochran, J.R., J.C. Sempéré, and the SEIR Scientific Team, The Southeast Indian Ridge between $88^{\circ} \mathrm{E}$ and $118^{\circ} \mathrm{E}$ : Gravity anomalies and crustal accretion at intermediate spreading rate, J. Geophys. Res., 102, 15,46314,487, 1997.

Collier, J., and M. Sinha, Seismic images of a magma chamber beneath the Lau Basin back-arc spreading centre, Nature, 346, 646-648, 1990.

Davis, R. E., Predictability of sea surface temperature and sea level pressure anomalies over the North Pacific Ocean, J. Phys. Oceanogr., 6, 249-266, 1976. 
Detrick, R. S., P. Buhl, E. E. Vera, J. C. Mutter, J. A. Orcutt, J. A. Madsen, and T. M. Brocher, Multichannel seismic imaging of the axial magma chamber along the East Pacific Rise between $9^{\circ} \mathrm{N}$ and $13^{\circ} \mathrm{N}$, Nature, $326,35-41,1987$.

Detrick, R. S., J. C. Mutter, P. Buhl, and I. I. Kim, No evidence from multichannel reflection data for a crustal magma chamber in the MARK area on the Mid-Atlantic Ridge, Nature, 347, 61-64, 1990.

Goff, J. A., A global and regional stochastic analysis of near-ridge abyssal hill morphology, J. Geophys. Res., 96, 21,713-21,737, 1991

Goff, J. A., and T. H. Jordan, Stochastic modeling of seafloor morphology: Inversion of Sea Beam data for second-order statistics, J. Geophys. Res., 93, 13,589-13,608, 19.88.

Goff, J. A., A. Malinverno, D. J. Fornari, and J. R. Cochran, Abyssal hill segmentation: Quantitative analysis of the East Pacific Rise flanks $7^{\circ} \mathrm{S}-9^{\circ} \mathrm{S}, J$. Geophys. Res., 98, 13,851-13,862, 1993.

Goff, J. A., B. E. Tucholke, J. Lin, G. E. Jaroslow, and M. C. Kleinrock, Quantitative analysis of abyssal hills in the Atlantic Ocean: A correlation between inferred crustal thickness and extensional faulting, J. Geophys. Res., 100, 22,509-22,522, 1995.

Goff, J.A., Y. Ma, A. Shah, J.R. Cochran, and J.C. Sempéré, Stochastic analysis of seafloor morphology on the flank of the Southeast Indian Ridge: The influence of ridge morphology on the formation of abyssal hills, $J$. Geophys. Res., 102, 15,521-15,534, 1997.

Hayes, D. E., and K. A. Kane, The dependence of seafloor roughness of spreading rate, Geophys. Res. Lett., 18, 1425-1428, 1991.

Heezen, B. C., The rift in the ocean floor, Sci. Am., 203, 99-110, 1960.

Kuo, B. Y., D. Forsyth, and E. M. Parmentier, Flexure and thickening of the lithosphere at the East Pacific Rise, Geophys. Res. Lett., 13, 681$684,1986$.

Lin, J., G. M. Purdy, H. Shouten, J. C. Sempéré, and C. Zervas, Evidence from gravity data for focused magmatic accretion along the MidAtlantic Ridge, Nature, 344, 627-632, 1990.

Lorenz, E. N., Empirical orthogonal functions and statistical weather prediction, Statistical Forecasting Project Tech. Rep. l, Dept. Meteorol., Mass. Inst. Technol., Cambridge, Mass., 1959.

$\mathrm{Ma}, \mathrm{Y}$., and J. R. Cochran, Transitions in axial morphology along the Southeast Indian Ridge, J. Geophys. Res., I0I, 15,849-15,866, 1996.

Macdonald, K. C., The crest of the Mid-Atlantic Ridge: Models for crustal generation processes and tectonics, in The Western North Atlantic Region, The Geology of North America, vol. M, edited by P. Vogt and B. Tucholke, pp. 51-68, Geol. Soc. Am., Boulder, Colo., 1986.

Macdonald, K. C., Tectonic and magmatic processes on the East Pacific Rise, in The Eastern Pacific Ocean and Hawaii, The Geology of North America, vol. N, edited by E. L. Winterer, D. M. Hussong and R. W. Decker, pp. 93-110, Geol. Soc. Am., Boulder, Colo,, 1989.

Macdonald, K. C., and P. J. Fox, The axial summit graben and crosssectional shape of the East Pacific Rise as indicators of axial magma chambers and recent volcanic eruptions, Earth Planet. Sci. Lett., 88, 119-131, 1988.

Madsen, J. A., D. W. Forsyth, and R. S. Detrick, A new isostatic model for the East Pacific Rise crest, J. Geophys. Res., 89, 9997-10,016, 1984.

Malinverno, A., Inverse square-root dependence of mid-ocean ridge flank roughness on spreading rate, Nature, 352, 58-60, 1991.

Malinverno, A., and P. A. Cowie, Normal faulting and the topographic roughness of mid-ocean ridge flanks, J. Geophys. Res., 98, 17,921$17,939,1993$

Menard, H. W., The East Pacific Rise, Science, 132, 1737-1746, 1960.

Menke, W., Geophysical Data Analysis: Discrete Inverse Theory, 2nd ed., 260 pp., Academic, San Diego, Calif., 1989.

Morton, J. L., and N. H. Sleep, Seismic reflections from a Lau Basin magma chamber, in Geology and Offshore Resources of Pacific Island Arcs- Tonga Region, Earth Sci. Ser., edited by D. W. Scholl and T. L. Vallier, pp. 441-453, Circum Pac. Coun. for Energy and Miner. Resour., Houston, Tex., 1985.

Morton, J. L., and N. H. Sleep, W. R. Normark, and D. H. Tompkins, Structure of the southern Juan de Fuca Ridge from seismic reflection records, J. Geophys. Res., 92, 11,315-11,326, 1987.
Mutter, J. C., S. M. Carbotte, W. Su, L. Xu, P. Buhl, R. S. Detrick, G. A. Kent, J. A. Orcutt, and A. J. Harding, Seismic images of active magma systems beneath the East Pacific Rise between $17^{\circ} 05^{\prime}$ and 17'35'S, Science, 268, 391-395, 1995.

Neumann, G. A., and D. W. Forsyth, The paradox of the axial profile: Isostatic compensation along the axis of the Mid-Atlantic Ridge?, $J$. Geophys. Res., 98, 17,891-17,910, 1993.

Parmentier, E. M., and J. Phipps Morgan, Spreading rate dependence of three-dimensional structure in oceanic spreading centres, Nature, 348, 325-328, 1990.

Phipps Morgan, J., and Y. J. Chen, Dependence of ridge-axis morphoiogy on magma supply and spreading rate, Nature, 364, 706$708,1993 a$.

Phipps Morgan, J., and Y. J. Chen, The genesis of oceanic crust: magma injection, hydrothermal circulation and crustal flow, $J$. Geophys. Res., 98, 6283-6297, 1993b.

Phipps Morgan, J., E. M. Parmentier, and J. Lin, Mechanisms for the origin of mid-ocean ridge axial topography: Implications for the thermal and mechanical structure of accreting plate boundaries, $J$. Geophys. Res., 92, 12,823-12,836, 1987.

Phipps Morgan, J., A. Harding, J. Orcutt, G. Kent, and Y. J. Chen, An observational and theoretical synthesis of magma chamber geometry and crystal genesis along a Mid-Ocean Ridge spreading center, Magmatic Systems, edited by M. P. Ryan, pp. 139-178, Academic, San Diego, Calif. 1994.

Purdy, G. M., and R. S. Detrick, Crustal strueture of the Mid-Atlantic Ridge at $23^{\circ} \mathrm{N}$ from seismic refraction, J. Geophys. Res., 91, 3739$3762,1986$.

Purdy, G. M., L. S. L. Kong, G. L. Christeson, and S. C. Solomon, Relationship between spreading rate and the seismic structure of midocean ridges, Nature, 355, 815-817, 1992.

Rohr, K. M. M., B. Milkereit, and C. J. Yorath, Asymmetric deep crustal structure across the Juan de Fuca Ridge, Geology, 16, 533-537, 1988.

Sempéré, J.C., J.R. Cochran, and the SEIR Scientific Team, The Southeast Indian Ridge between $88^{\circ} \mathrm{E}$ and $118^{\circ} \mathrm{E}$ : Variations in crustal accretion at constant spreading rate, J. Geophys. Res., 102, 15,489-14,505, 1997.

Sleep, N. H., Sensitivity of heat flow and gravity to the mechanism of sea-floor spreading, J. Geophys. Res., 74, 542-549, 1969.

Small, C., A global analysis of mid-ocean ridge axial topography, Geophys. J. Int., 116, 64-84, 1994.

Small, C., and D. T. Sandwell, An analysis of ridge axis gravity roughness and spreading rate, J. Geophys. Res., 97, 3235-3245, 1992.

Small, C., and D. T. Sandwell, Imaging mid-ocean ridge transitions with satellite gravity, Geology, 22, 123-126, 1994.

Tapponnier, $\mathrm{P}$,, and $J$. Francheteau, Necking of the lithosphere and the mechanics of slowly accreting plate boundaries, J. Geophys. Res., 83, 3955-3970, 1978.

Tolstoy, M., A. J. Harding, J. A. Orcutt, and J. Phipps Morgan, Crustal thickness at the Australian Antarctic Discordance and neighboring Southeast Indian Ridge, Eos Trans. AGU, 76(46), Fall Meet. Suppl., F570, 1995.

Wang, X., and J. R. Cochran, Gravity anomalies, isostasy, and mantle flow at the East Pacific Rise crest, J. Geophys. Res., 98, 19,505$19,531,1993$.

Wang, X., J. R. Cochran, and G. A. Barth, Gravity anomalies, crustal thickncss, and the pattern of mantle flow at the fast-spreading East Pacific Rise, $9^{\circ}-10^{\circ} \mathrm{N}$ : Evidence for three-dimensional upwelling, $J$. Geophys Res., 101, 17,927-17,940, 1996.

J.R. Cochran and L.Y. Ma, Lamont-Doherty Earth Observatory of Columbia University, Palisades, NY 10964. (e-mail: jrc@1deo.columbia.edu; maying@1deo.columbia.edu)

(Received September 16, 1996; revised March 12, 1997; accepted April 25, 1997.) 